\title{
Overall Equipment Effectiveness to Increase Productivity of Injection Molding Machine: A Case Study in Plastic Manufacturing Industry
}

\author{
Sunadi $^{1 *}$, Humiras Hardi Purba², and Else Paulina ${ }^{3}$ \\ ${ }^{1-3}$ Master of Industrial Engineering Program, Mercu Buana University \\ Jln. Meruya Selatan No.1, Jakarta Barat 11650, Indonesia \\ ${ }^{1}$ sunadi210770@gmail.com; ${ }^{2 h}$ ardipurba@yahoo.com; ${ }^{3} 31$ sesinulingga@gmail.com
}

Received: $12^{\text {th }}$ September 2020/ Revised: $20^{\text {th }}$ October 2020/ Accepted: $23^{\text {rd }}$ October 2020

How to Cite: Sunadi, Purba, H. H., \& Paulina, E. (2021). Overall Equipment Effectiveness to Increase Productivity of Injection Molding Machine: A Case Study in Plastic Manufacturing Industry. ComTech: Computer, Mathematics and Engineering Applications, 12(1), 53-64. https://doi.org/10.21512/comtech.v12i1.6706

\begin{abstract}
In line with the unstable market conditions in Indonesia, especially the plastic manufacturing industry, the companies need to be well prepared to survive. There were two research goals. First, it was to find out why the Overall Equipment Effectiveness (OEE) rate at the company did not meet the expected standard. Second, it was to determine what improvement should be made to increase the OEE for the machine. The research applied a case study in one of the plastic manufacturing industries located in Tangerang, Indonesia. It focused on the performance of Toshiba injection molding machine number 42/IS $450 \mathrm{GSW}$. The analysis was performed by applying Failure Mode and Effect Analysis (FMEA) with support from other tools such as Pareto chart, Cause and Effect Diagram (CED), and six big losses. By following the whole framework of the research, it finds causes of why the OEE does not meet the target. Then, from the results, it can be concluded that the
\end{abstract}

implementation of the methods has a positive impact on the company. The OEE rate increases from an average of $26,43 \%$ to $78,87 \%$. It means the OEE rate has achieved the company target of $75 \%$.

Keywords: Overall Equipment Effectiveness, company productivity, injection molding machine, plastic manufacturing industry

\section{INTRODUCTION}

The instability of economic growth becomes a serious discussion for many companies in the world, especially manufacturing or service company. Because of that situation, the company needs to anticipate it by maintaining its operation. Many ways can be done by the company to survive and maintain its continuity of business operations. One of the ways is closely monitoring productivity and quality of products.

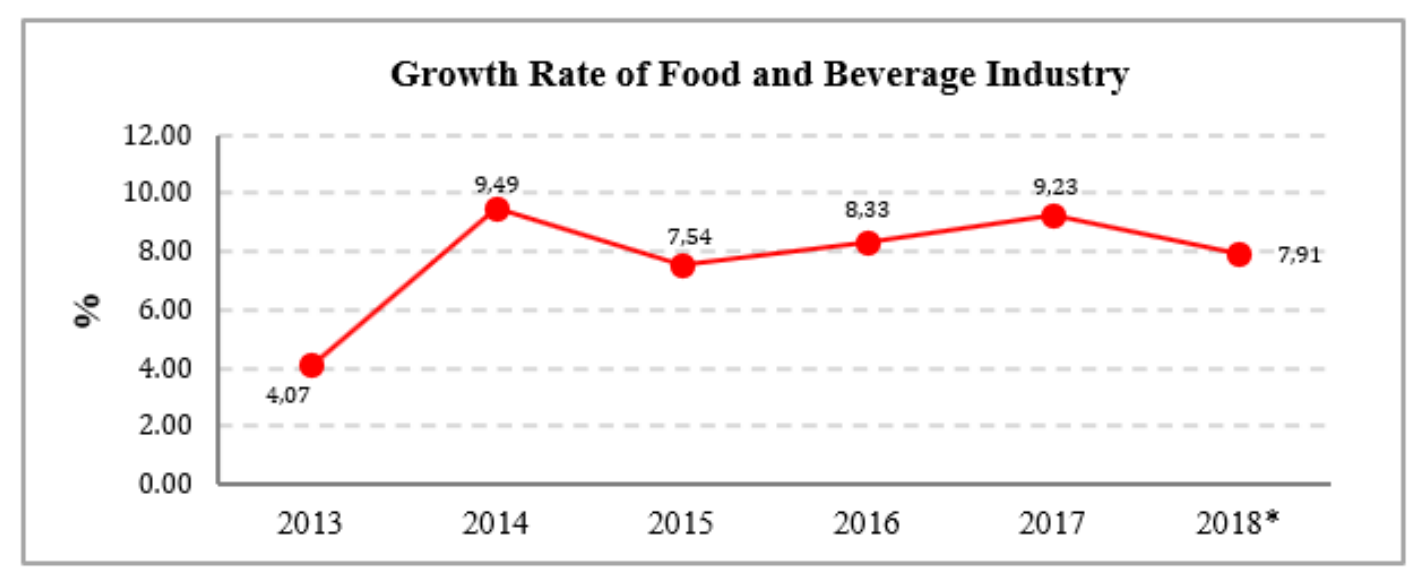

Figure 1 The Growth Rate of the Food and Beverage Industry (2013-2018)

(Source: Biro Pusat Statistik (BPS), 2018) 
The food and beverage industry is one of the opportunities for the packaging industry. This industry grows in Indonesia in the last six years, as shown in Figure 1. Since 2013, it has increased significantly (Biro Pusat Statistik (BPS), 2018). However, in 2018, the growth was $7,91 \%$, which decreased by $1,32 \%$ from the previous year.

Fluctuation in the growth rate of the food and beverage industry becomes a trigger for tightening competition for the related industry like the plastic manufacturing industry. The improvement in production and product quality are needed. So, to win the competition, every company must increase the ability to have an efficient process and good product quality (Cheah, Prakash, \& Ong, 2020). Improving the quality and productivity is essential for the manufacturing industry to become a winner in global competition (Tobe, Widhiyanuriyawan, \& Yuliati, 2018; Reddy, Rao, \& Rajyalakshmi, 2016).

Quality and productivity are important terms in the manufacturing industry. Sometimes, it is difficult to understand what priorities should be set to improve the process efficiency. So, it requires experts in a company (Gidey, Beshah, \& Kitaw, 2014). Overall Equipment Effectiveness (OEE) is a method that can be applied in industry to improve the productivity of the process. So, the OEE rate should be well controlled and monitored. Nurprihatin, Angely, and Tannady (2019) focused their research on downtime analysis and calculating OEE in one of the food industries in Indonesia. It resulted in the OEE rate with the international common standard that was due to low availability rate. Then, the researchers suggested implementing the Total Productive Maintenance (TPM). Similarly, Darsin (2020) mentioned that close monitoring of the OEE rate could reduce downtime. Gupta and Garg (2012) also emphasized TPM in the importance of making a sustainable attitude for improvement, improving quality, and making employees work together simultaneously.

Moreover, the used machines or equipment in manufacturing industries are sometimes unable to be managed well. The stoppage of the process due to downtime results in an inefficient process for the company. Thus, maintaining the machine regularly is essential for keeping it work well (Siregar, Purba, \& Aisyah, 2017). For example, Wahyudin and Hasibuan (2019) did a case study of the shoe industry in Tangerang, Indonesia, by utilizing the time of TPM and providing some suggestions to improve the assembly line. As a result, the OEE rate increased from $61,37 \%$ to $72,24 \%$ on average in $2017-2018$. The other previous studies that focus on manufacturing are Singh and Narwal (2017), Chong, Ng, and Goh (2015), Shakil and Parvez (2018), Nallusamy and Majumdar (2017), and Ranjan and Mishra (2016).

The mentioned explanation shows that the machine and other supporting equipment in the production process are essential. Then, stoppage and ineffectiveness during the production process and the decrease in the product quality should be eliminated.
The efforts to make improvements should be managed well to be efficient and effective.

Related to the literature review that the researchers have compiled, it will be limited to the manufacturing company, especially in the plastics manufacturing industry. The research conducts a case study in a plastic manufacturing industry which is located in Tangerang, Indonesia. For three months (October, November, and December in 2019), the OEE rate is not satisfied yet with the average rate of $26,43 \%$. This condition impacts low productivity, so the company needs to improve the OEE rate by increasing its productivity. This issue is the reason why the researchers conduct the research. There are two goals of the research. First, it aims to find out why the OEE rate at the company does not meet the expected standard. Second, it is to determine what improvement should be made to increase the OEE rate for the machine. The research is done by applying Failure Mode and Effect Analysis (FMEA) with support from other tools such as Pareto chart, Cause and Effect Diagram (CED), and six big losses. The researchers expect the OEE value can be increased.

TPM is an essential thing in Japanese concepts or philosophy. It was developed based on the concept and methodology of production maintenance. This concept was first popularized by Nippon Denso Co. Ltd. from Japan, which was a supplier of Toyota Motor Company in 1971 (Waghmare, Raut, Mahajan, \& Bhamare, 2014). According to Badli Shah (2012), TPM is very important to make the assets owned by the company always in good condition so that it can increase manufacturing productivity. It is an innovative maintenance approach to optimize equipment effectiveness, eliminate damage, and promote autonomous maintenance by involving the total workforce. It is a world-class manufacturing initiative to optimize the effectiveness of manufacturing equipment (Shirose, 1995). It involves the workers from all departments and levels, from employees to senior executives, to ensure more effective operations. Through proper and suitable maintenance programs, major losses due to breakdowns and defects can be avoided. Even though these maintenance programs will cost money, the lack of maintenance will cost even more (Salonen \& Deleryd, 2011). TPM program aims to improve productivity and quality along with increased employees' morale and job satisfaction (Singh, Gohil, Shah, \& Desai, 2013). It has become more popular not only due to its ability to improve performance but also its emphasis on human capital resources. There are many recent studies in the form of case studies and surveys related to TPM (Mad Lazim \& Ramayah, 2010; Ahuja \& Singh, 2012). The success in implementing TPM improves the manufacturing productivity and brings good morale for the employee so it can reduce the cost of maintenance (Lazim, Salleh, Subramaniam, \& Othman, 2013).

There are eight pillars to increase labor productivity, reduction in maintenance costs, and reduction in production stoppages and downtimes on 
the TPM implementation. The eight pillars of TPM are autonomous maintenance, focused maintenance, planned maintenance, quality maintenance, education and training, office TPM, development management and safety and health at work, and environment protection (Sangameshwran \& Jagannathan, 2002; Prabowo, Suprapto, \& Farida, 2018; Supriyadi, Ramayanti, \& Afriansyah, 2017). The most important metric to track the effectiveness of the TPM implementation in an organization is the OEE (Zammori, Braglia, \& Frosolini, 2011). It is not only used as an operational measure, but also serves as an indicator of process improvement activities within the manufacturing environment (Dal, Tugwell, \& Greatbanks, 2000).

OEE is a part of TPM. It is a comprehensive measure that identifies the level of machine/equipment productivity and performance in theory. This measurement is very important to know which areas need to increase its productivity or efficiency of the machine/equipment and show the bottleneck area in the production line (Gandhi \& Deshpande, 2018). It is also a measurement tool to evaluate and improve the system to guarantee the increased productivity in the machine and equipment (Nakajima, 1988).

The purpose of OEE is to measure the performance of a maintenance system. Using this method, it can see the availability of machines/ equipment, production efficiency, and the quality of the output of the machines/equipment. The OEE score is derived from the multiplication of three elements: availability, production effectiveness, and quality rate (Yusuf, Rahman, \& Himawan, 2015). The equation is as follows:

$$
O E E=(A \times P \times Q) \times 100 \%
$$

Where:

Availability (A):

$$
\begin{aligned}
& (A)=\frac{\text { operating time }(h)}{\text { Loading time }(h)} \times 100 \% \\
& \text { Operating time }=\text { Loading time }(h)-\text { Downtime }(h)
\end{aligned}
$$

Performance Efficiency $(\mathrm{P})$ :

$$
(P)=\frac{\text { operating time }(h)}{\text { Loading time }(h)} \times 100 \%
$$

Quality Rate (Q):

$$
(Q)=\frac{\text { Total production }- \text { def ect amount }}{\text { Total production }(\text { units })} \times 100 \%
$$

According to Nakajima (1988), the carried out activities and actions do not only focus on preventing damage and minimizing downtime. However, many factors can cause losses due to the low efficiency of the machine or equipment. Low productivity of machines or equipment is caused by ineffective and inefficient utilization. There are six big losses. These three types of losses are associated with the production process, which must be anticipated: downtime loss that affects the availability rate, speed loss that impacts performance rate, and a quality loss that affects the quality rate.

The six big losses are categorized into three main categories based on the aspects of loss: downtime losses, speed losses, and defects losses. First, downtime consists of breakdown, set-up, and adjustment. Equipment failure or breakdown loss is categorized as time loss when productivity is reduced, and quality is lost caused by defective products. Set-up or adjustment time losses have resulted from downtime and defective products that occur when the production of one item ends. The equipment is adjusted to meet the requirements of another item. Second, speed losses include idling and minor stoppages and reduced speed. Idling and minor stop occur when production is interrupted by a temporary malfunction or when a machine is idling.

Meanwhile, reduced speed losses refer to the difference between the equipment design speed and the actual operating speed. Third, defects consist of defects in the process and reduced yield. Reduced yield occurs during the early stage of production from machine start-up stabilization. Quality defects and rework are losses in quality caused by malfunctioning equipment.

Many researchers study the six big losses in the manufacturing industries. Pinjar, Shivakumar, and Patil (2015) used Single-Minute Exchange of Die (SMED) implementations. It was a theory and set of techniques to reduce equipment's set-up time and changeover operations in less than 10 minutes. In other words, it was in the single-minute range. Benjamin, Murugaiah, and Marathamuthu (2013) mentioned that SMED could eliminate small stops in the manufacturing process. Moreover, Rusman, Parenreng, Setiawan, Asmal, and Wahid (2019) stated that the measurement of maintenance effectiveness level was needed to reduce six big losses. Then, Mardono, Rimawan, Pratondo, and Saraswati (2019) suggested that by intensively evaluating six big losses in the manufacturing industry, it could increase productivity and reduce the fixed and variable cost. Six big losses are calculated as follows.

$$
\text { Breakdown Losses }=\frac{\text { Breakdown time }}{\text { Loading time }} \times 100 \%
$$

$$
\begin{aligned}
& \text { Set-up losses }=\frac{\text { Set-up time }}{\text { Loading time }} \times 100 \% \\
& \text { Speed losses }=\frac{\text { Available Time- }\left(\frac{\text { ouput }}{\text { speed }}\right)}{\text { Loading Time }} \times 100 \% \\
& \text { Stoppage losses }=\frac{\text { Non Productivity }}{\text { Loading Time }} \times 100 \% \\
& \text { Quality Loss }=\frac{\text { Def ect }+ \text { Rework } / \text { Speed }}{\text { Loading time }} \times 100 \%
\end{aligned}
$$


Start - up losses $=\frac{\text { Defect } \text { when start-up/speed }}{\text { Loading time }} \times 100 \%$

Next, FMEA is a systematic failure analysis method to identify and prevent the process and product. It allows engineers to define, identify, measure, analyze, and eliminate all potential problems before starting the production (McDermott, Mikulak, \& Beauregard, 2009). FMEA is developed in the United States Military. It was included in the military procedure of MIL-P-1629, titled Procedures for Performing a Failure Mode, Effects and Criticality Analysis, on November $9^{\text {th }}, 1949$. It was formalized as a design methodology in the 1960s by the aerospace industry, with its obvious reliability and safety requirements. In the late 1970s, the Ford Motor Company introduced FMEA to the automotive industry for safety and regulatory consideration (Ćatić \& Glišović, 2019).

The main purpose of FMEA is to prevent the possibility that a new design, process, or system fails to achieve totally or in part of the proposed requirements under certain conditions, such as defined purpose and imposed limits. According to Chrysler LLC, Ford Motor Company, and General Motors Corporation (2008), FMEA implementations identify the causes of process failures in fulfilling customers' needs, estimate the risk of certain causes of the failure, and evaluate it. Moreover, previous research overcomes machine stops and more hours during production that caused low OEE using the FMEA approach (Susilo \& Andika, 2016). According to McDermott et al. (2009), there are ten steps to implement FMEA, as shown in Table 1.

Table 1 Steps of Failure Mode and Effect Analysis (FMEA)

\begin{tabular}{|c|c|}
\hline Steps & Descriptions \\
\hline 1 & Reviewing process or product \\
\hline 2 & Brainstorming the mode of potential failure \\
\hline 3 & $\begin{array}{l}\text { Making a list of the potential effects for each mode } \\
\text { failure }\end{array}$ \\
\hline 4 & Assigning severity ratings for each effect \\
\hline 5 & Assigning an occurrence rating for each effect \\
\hline 6 & Assigning detection ratings for each inflicted effect \\
\hline 7 & $\begin{array}{l}\text { Calculating the Risk Priority Number (RPN) for each } \\
\text { of the inflicted securities }\end{array}$ \\
\hline 8 & Prioritizing the failure modes that will be followed up \\
\hline 9 & $\begin{array}{l}\text { Taking action to eliminate or reduce high-risk failure } \\
\text { modes }\end{array}$ \\
\hline 10 & $\begin{array}{l}\text { Calculating the results of the RPN after the failure } \\
\text { mode has been reduced or eliminated }\end{array}$ \\
\hline
\end{tabular}

The RPN is used to prioritize potential failures. It consists of occurrence (how likely is the cause and failure mode to occur?), severity (how serious is the impact of the end effect?), and detection (how difficult is the cause and failure mode to be detected?). It can be calculated using Equation (12).

$R P N=$ Occurance $(O) \times$ Severity $(S) \times$ Detection $(D)$

Next, CED is a visual tool to logically organize possible causes for a specific problem or effect by graphically displaying them. It is done by increasing the details and suggesting causal relationships among theories (Xu \& Dang, 2020). According to Nasution (2005), CED is commonly called a fishbone diagram, which was developed by Kaoru Ishikawa in 1934 and is known as the Ishikawa diagram. It can be used to determine the root cause of a problem. The structured approach, which is applied in CED, considers more detail in finding the causes of a problem, discrepancies, and gaps that occur. There are six main factors to analyze the CED: man, method, machine, material, environment, and management. The factors are shown in Figure 2.

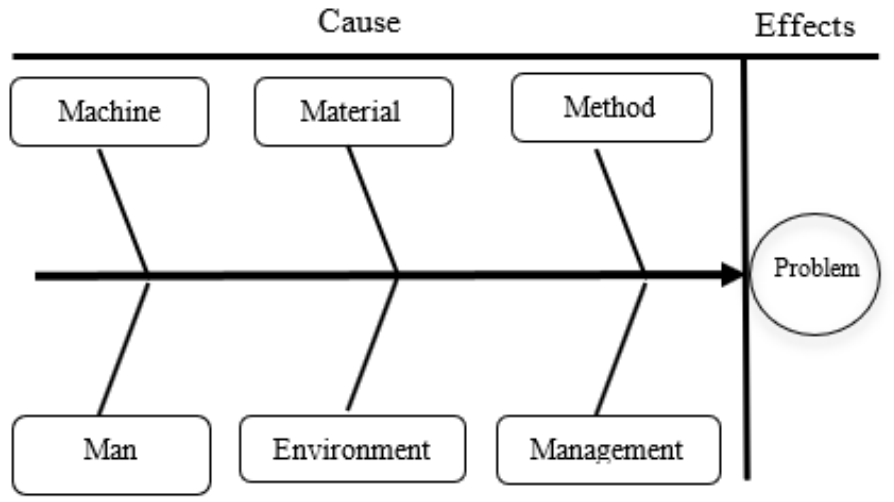

Figure 2 Cause and Effect Diagram

Then, the Pareto principle (also known as the 8020 rule) states that about $80 \%$ of the implications are produced by $20 \%$ of the causes for many phenomena. It is often used in management, economics, and business to improve productivity and make better decisions. Thus, it is important for real-life problems solution (Dunford, Su, \& Tamang, 2014).

Sutardi and Budiasih (2011) mentioned that Joseph Juran was the first to show that Pareto was a "universal" principle. In the early 1950s, Juran noted the "universal" phenomenon, which he called the Pareto Principle. Each group of factors contributed to a general effect. A relatively small number was responsible for most of its effects. It was applied in a variety of astounding situations, not just economic activity, and seemed to have survived without exception in terms of quality.

He also coined the terms "vital view" and "useful many" or "trivial many" to refer to some contributions, which explained most of the effects and others who were responsible for the smaller proportion of the effect.

Pareto diagrams also discuss issues that significantly affect quality improvement and provide 
guidance in allocating limited resources to solve problems. Besides, it can compare processes from before and after improvement (Samuel, Oyawale, \& Fayomi, 2019). Creating the Pareto diagram is explained in the following sequence. First, the researchers determine the method for clarifying data based on problems, causes, types of discrepancies, and others. Second, the researchers determine the used units to sequence these characteristics, such as Rupiah, frequency, and units. Third, the researchers collect data according to a predetermined time interval. Fourth, the researchers summarize and rank the data from the largest. Fifth, the researchers calculate the used frequency or cumulative percentage. Sixth, the researchers make the bar diagram.

\section{METHODS}

The research applies a quantitative method. Data collection is taken from the production and quality records of the plastic manufacturing industry in Tangerang, Indonesia. The sample is Toshiba injection molding machine number 42/IS $450 \mathrm{GSW}$. OEE data are obtained by calculating based on three factors: availability, performance, and quality. The calculation was illustrated for three months period (October, November, and December 2019). Data calculation and analysis as the framework research are shown in Figure 3. The sequence of Figure 3 is as follows. First, the research collects the availability rate, performance rate, and quality rate. Second, it analyzes the six big losses and FMEA and determines the cause for losses using CED. Third, the improvement will be determined. Fourth, after the improvement is made, the researchers conduct an OEE evaluation.

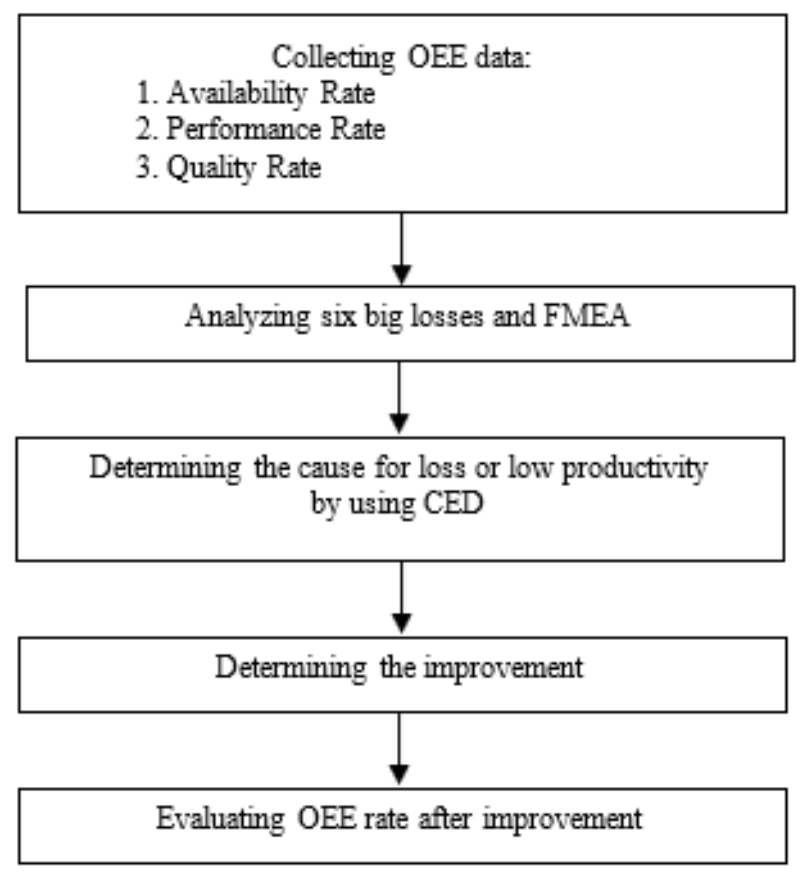

Figure 3 Research Framework

\section{RESULTS AND DISCUSSIONS}

The data are taken from daily production performance records at the plastic manufacturing industry in Tangerang, Indonesia. It focuses on the performance of Toshiba injection molding machine number 42/IS 450 GSW. The tonnage machine specification is 450 tons. The OEE rate for three months (October, November, and December 2019) is shown in Table 2.

Table 2 OEE Rate of Toshiba Injection Molding Machine Number 42/IS 450 GSW in Percentage

\begin{tabular}{lcccc}
\hline Items & Oct. & Nov. & Dec. & Average \\
\hline Availability & 61,61 & 60,49 & 42,82 & 54,97 \\
Performance Rate & 45,08 & 45,92 & 54,63 & 48,54 \\
Quality Rate & 99,54 & 98,76 & 98,79 & 99,03 \\
OEE & 27,65 & 27,43 & 23,11 & 26,43 \\
\hline
\end{tabular}

(Source: Plastic Manufacturing Industry)

The average OEE rate for injection molding no 42/IS $450 \mathrm{GSW}$ for the three months is calculated using Equation (1). The results show $54,97 \%$ of availability, $48,54 \%$ of performance, and $99,03 \%$ of quality. The trend of OEE is observed. The calculation can be seen as follows.

$$
\begin{aligned}
O E E & =54,97 \% \times 48,54 \% \times 99,03 \% \times 100 \% \\
& =26,43 \%
\end{aligned}
$$

Then, Table 3 shows the actual OEE data from the calculation and the international standard as guidelines to assess the performance of an injection molding machine. It also includes the rates of availability, performance, and quality that the company achieves. The OEE is $26,43 \%$. It is still below the target. Thus, the company needs to make good strategies to achieve the OEE target.

Table 3 International Guidelines and Actual Achievement

\begin{tabular}{lcc}
\hline Parameter & Target & Actual Achievement \\
\hline OEE & $>85 \%$ & $26,43 \%$ \\
Availability & $>95 \%$ & $54,97 \%$ \\
Performance & $95 \%$ & $48,54 \%$ \\
Quality & $99,90 \%$ & $99,03 \%$ \\
\hline
\end{tabular}

From the results in Table 3, several factors affect it. Those factors are breakdown, set-up and adjustment, reduced speed loss, minor loss, defect loss, and start-up. All factors are taken from the production data records. Table 4 shows all contributing factors. 
Table 4 Influencing Factors that Reflect on OEE

\begin{tabular}{llll}
\hline Items* & A & P & Q \\
\hline Breakdown & $\sqrt{ }$ & & \\
Set-up and adjustment & $\sqrt{ }$ & & \\
Reduced speed loss & & $\sqrt{ }$ & \\
Minor stops loss & $\sqrt{ }$ & \\
Defect loss & & & $\sqrt{ }$ \\
Start-up & & & $\sqrt{ }$ \\
\hline
\end{tabular}

Note: $\mathrm{A}=$ Availability, $\mathrm{P}=$ Performance, and $\mathrm{Q}=$ Quality.

Then, observation is done to collect the production information, which is related to loading time, breakdown time, set-up time, minor stoppage time, available time, speed, output production, and defect unit. It is done directly in the plastic manufacturing industry. During observation, the relevant department at this company helps the process. The collected data are shown in Table 5.

Table 5 Production Data in 2019

\begin{tabular}{|c|c|c|c|c|}
\hline Descriptions & Oct. & Nov. & Dec. & Average \\
\hline $\begin{array}{l}\text { Loading time } \\
\text { (Hours) }\end{array}$ & 400 & 350 & 380 & 377 \\
\hline Breakdown (Hours) & 150 & 120 & 180 & 150 \\
\hline Set-up (Hours) & 2,8 & 16,5 & 25 & 15 \\
\hline $\begin{array}{l}\text { Minor stoppage } \\
\text { (Hours) }\end{array}$ & 0,75 & 1,8 & 12,3 & 5 \\
\hline $\begin{array}{l}\text { Available time } \\
\text { (Hours) }\end{array}$ & 246 & 212 & 163 & 207 \\
\hline Speed (Unit/hours) & 360 & 360 & 360 & 360 \\
\hline $\begin{array}{l}\text { Output production } \\
\text { (Units) }\end{array}$ & 40.000 & 35.000 & 32.000 & 35.667 \\
\hline Rework (Units) & 45 & 200 & 100 & 115 \\
\hline Defect (Units) & 80 & 150 & 250 & 160 \\
\hline $\begin{array}{l}\text { Defect start-up } \\
\text { (Units) }\end{array}$ & 60 & 85 & 38 & 61 \\
\hline
\end{tabular}

(Source: Plastic Manufacturing Industry)

After getting the production data, the analysis is followed by six big losses. The calculation of six big losses covers breakdown, set-up, and adjustment, reduced speed, minor stoppage, defect, and startup. The research shows the calculation with a focus on October as a sample. Using Equation (6), the calculation of breakdown losses is as follows.

$$
\text { Breakdown losses }=\frac{150}{400} \times 100 \%=37,5 \%
$$

Using the same way to calculate breakdown for the other months obtains $34,29 \%$ for November and
$47,37 \%$ for December. Based on the calculation, the highest breakdown happens in December, with a total breakdown of 180 hours or $47,37 \%$. The accumulated total downtime from October to December 2019 is 140 hours or $39,82 \%$ of loading time. The calculation results are shown in Table 6 .

Table 6 Breakdown Data in October,

November, and December 2019

\begin{tabular}{lccc}
\hline Month & $\begin{array}{c}\text { Loading Time } \\
\text { (Hours) }\end{array}$ & $\begin{array}{c}\text { Breakdown } \\
\text { (Hours) }\end{array}$ & $\begin{array}{c}\text { Breakdown } \\
\text { losses (\%) }\end{array}$ \\
\hline October & 400 & 150 & 37,50 \\
November & 350 & 120 & 34,29 \\
December & 380 & 180 & 47,37 \\
\hline Total & 1.130 & 450 & 39,82 \\
\hline
\end{tabular}

(Source: Processed data, 2019)

Set-up and adjustment losses are the needed total time to change parts starting from the stopped machine until the machine running again. It is calculated using Equation (7). The set-up losses are obtained from the result of dividing between set-up time and loading time and multiplying it with $100 \%$. For example, the set-up losses for October 2019 are as follows.

$$
\text { Set-Up losses }=\frac{2.8}{400} \times 100 \%=0,7 \%
$$

Then, using the same way, the research also calculates set-up losses for the other months. It obtains $4,7 \%$ in November and 6,6\% in December. The lowest set-up losses occur in October, and the highest is in December. The reason for the highest set-up losses in December is due to 25 hours for the set time. The calculations can be seen in Table 7 .

Table 7 Set-Up Data in October, November, and December 2019

\begin{tabular}{lccc}
\hline Description & $\begin{array}{c}\text { Loading Time } \\
\text { (Hours) }\end{array}$ & $\begin{array}{c}\text { Set-up } \\
\text { (Hours) }\end{array}$ & $\begin{array}{c}\text { Set-up } \\
\text { losses (\%) }\end{array}$ \\
\hline October & 400 & 2,8 & 0,7 \\
November & 350 & 16,5 & 4,7 \\
December & 380 & 25,0 & 6,6 \\
\hline Total & 1.130 & 44,3 & 3,92 \\
\hline
\end{tabular}

(Source: Processed data, 2019)

The speed loss is the down machine speed from the actual and standard speed. It is calculated using Equation (8). The result is obtained by dividing the available time minus output which is divided by speed with loading time. The example of calculating for the month of October is as follows. 


$$
\begin{aligned}
\text { Speed losses } & =\frac{246-\left(\frac{40.000}{360}\right)}{400} \times 100 \% \\
& =33,7 \%
\end{aligned}
$$

Using the same way to calculate the speed losses, the results for the other months are obtained. It shows $32,7 \%$ in November and $19,4 \%$ in December. The highest speed loss happens in October with a total of 135,34 hours, and the lowest is in December with a total of 73,81 hours. The total of reduced speed within three months is 323,63 hours, or the total speed loss is $28,6 \%$. The calculation results are shown in Table 8 .

Table 8 Reduced Speed Data in October, November, and December 2019

\begin{tabular}{lccc}
\hline Description & $\begin{array}{c}\text { Loading Time } \\
\text { (Hours) }\end{array}$ & $\begin{array}{c}\text { Speed Reduce } \\
\text { (Hours) }\end{array}$ & $\begin{array}{c}\text { Speed Reduce } \\
\text { Losses (\%) }\end{array}$ \\
\hline October & 400 & 135,34 & 33,7 \\
November & 350 & 114,48 & 32,7 \\
December & 380 & 73,81 & 19,4 \\
\hline Total & 1.130 & 323,63 & 28,6 \\
\hline
\end{tabular}

The stoppage losses are categorized as minor stops. It is calculated by using Equation (9). The results are obtained by dividing non-productivity and loading time and multiplying it by $100 \%$. Here is an example of the stoppage losses calculation for October 2019.

$$
\text { Stoppage losses }=\frac{0,75}{400} \times 100 \%=0,19 \%
$$

Then, the calculation shows $0,51 \%$ for November and 3,24\% for December. December has the highest stoppages losses with 12,3 hours. It is accumulated from the minor stoppages due to the heater nozzle problem. The data can be seen in Table 9.

Table 9 Minor Stoppage Data in October, November, and December 2019

\begin{tabular}{lccc}
\hline Descriptions & $\begin{array}{c}\text { Loading } \\
\text { Time (Hour) }\end{array}$ & $\begin{array}{c}\text { Stoppage } \\
\text { (Hours) }\end{array}$ & $\begin{array}{c}\text { Stoppages } \\
\text { Losses (\%) }\end{array}$ \\
\hline October & 400 & 0,75 & 0,19 \\
November & 350 & 1,80 & 0,51 \\
December & 380 & 12,30 & 3,24 \\
\hline Total & 1.130 & 14,85 & 1,31 \\
\hline
\end{tabular}

The defect losses are all the defective products. Those products do not meet the standard. It is calculated using Equation (10). The defect losses are obtained from dividing defect and rework per speed divided by loading time. Here is the example of calculating data for October 2019.

$$
\begin{aligned}
\text { Defect Loss } & =\frac{(80+45) / 360}{400} \times 100 \% \\
& =0,086 \%
\end{aligned}
$$

In the same way, it obtains $0,277 \%$ for November and $0,255 \%$ for December. Based on the calculation, the highest defect losses happen in November, and the lowest is in October. The highest defect losses in November are due to rework activities. In the meantime, the loading time is too low (350 hours). The results are shown in Table 10.

Table 10 Defect Losses in October, November, and December 2019

\begin{tabular}{lccc}
\hline Descriptions & $\begin{array}{c}\text { Loading Time } \\
\text { (Hours) }\end{array}$ & $\begin{array}{c}\text { Defect } \\
\text { (Hours) }\end{array}$ & $\begin{array}{c}\text { Defect } \\
\text { Losses (\%) }\end{array}$ \\
\hline October & 400 & 0,35 & 0,086 \\
November & 350 & 0,97 & 0,277 \\
December & 380 & 0,97 & 0,255 \\
\hline Total & 1.130 & 2,29 & 0,20 \\
\hline
\end{tabular}

Start-up losses happen because of defects during start-up time. It can be calculated by setting up the machine until the machine runs smoothly. The calculation uses Equation (11). An example is a calculation for October.

$$
\begin{aligned}
\text { Start-up losses } & =\frac{60 / 360}{400} \times 100 \% \\
& =0,042 \%
\end{aligned}
$$

By using the same way, the research obtains $0,001 \%$ for November and $0,062 \%$ for December. The start-up losses in December get the highest score because of defects during high start-up. The lowest start-up losses are in November, with a loading time of 350 hours. The calculation results are shown in Table 11 .

Table 11 Start-Up Losses in October, November, and December 2019

\begin{tabular}{lccc}
\hline Descriptions & $\begin{array}{c}\text { Loading } \\
\text { Time } \\
\text { (Hours) }\end{array}$ & $\begin{array}{c}\text { Start-Up } \\
\text { Losses } \\
\text { (Hours) }\end{array}$ & $\begin{array}{c}\text { Start-Up } \\
\text { Losses } \\
\text { (\%) }\end{array}$ \\
\hline October & 400 & 0,16 & 0,042 \\
November & 350 & 0,002 & 0,001 \\
December & 380 & 0,24 & 0,062 \\
\hline Total & 1.130 & 0,41 & 0,036 \\
\hline
\end{tabular}

The data are summarized in Table 12 to make it easier to analyze the six big losses. The highest loss is the breakdown. Then, it is followed by speed losses, set-up and adjustment, minor stoppage, defect losses, and start-up. After all the data are complete, it is put the Pareto chart in Figure 4. 
Table 12 Summary of Six Big Losses Analysis

\begin{tabular}{lc}
\hline Six Big Losses & Total Time Loss (Hours) \\
\hline Breakdown losses & 450 \\
Set-up and adjustment & 44,3 \\
Speed losses & 323,63 \\
Minor stoppage loss & 14,85 \\
Defect losses & 2,29 \\
Start-up losses & 0,41 \\
\hline
\end{tabular}

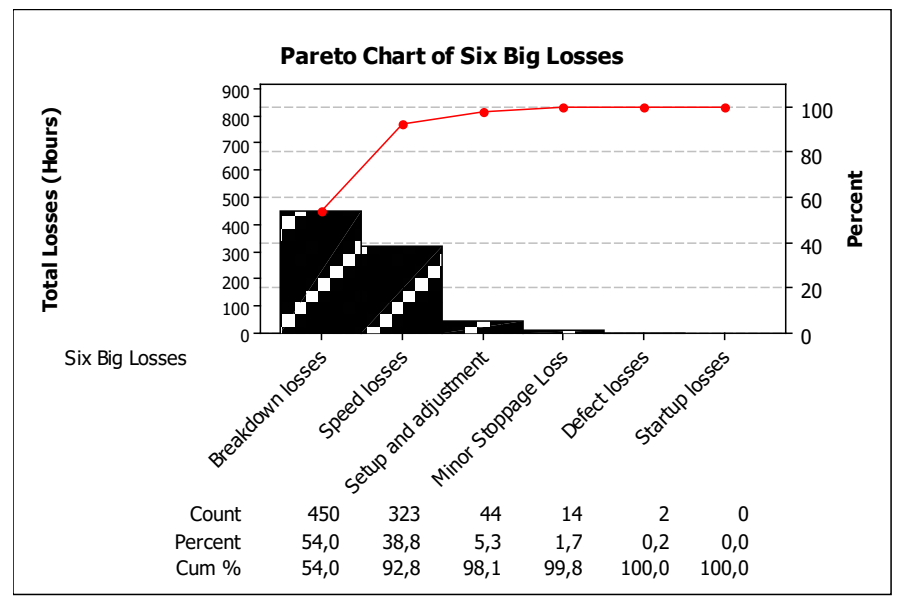

Figure 4 Pareto Chart of Six Big Losses

According to Figure 4, break down, speed losses, and set-up adjustment are the dominant contributor to six big losses. Breakdown losses are $53,9 \%$. It is followed by speed losses with $38,7 \%$. It needs an improvement in these dominant factors to minimize losses. The details of the breakdown are shown in Table 13.

Table 13 Breakdown Data for October, November, and December 2019

\begin{tabular}{lccc}
\hline Breakdown type & $\begin{array}{c}\text { Oct. } \\
\text { (Hours) }\end{array}$ & $\begin{array}{c}\text { Nov. } \\
\text { (Hours) }\end{array}$ & $\begin{array}{c}\text { Dec. } \\
\text { (Hours) }\end{array}$ \\
\hline Broken machine & 100 & 80 & 70 \\
Waiting for tooling & 50 & 35 & 15 \\
Wrong materials & 15 & 10 & 10 \\
Cleaning nozzle & 15 & 5 & 5 \\
Setting automation & 10 & 8 & 2 \\
Broken crane & 10 & 3 & 3 \\
Power off & 5 & 0 & 0 \\
\hline Total & 205 & 141 & 105 \\
\hline
\end{tabular}

There are seven breakdown types, as mentioned in Table 13. The broken machine and waiting for tooling are the biggest contributors to breakdown. Overall, the breakdown goes down. Figure 5 is the Pareto chart for breakdown.

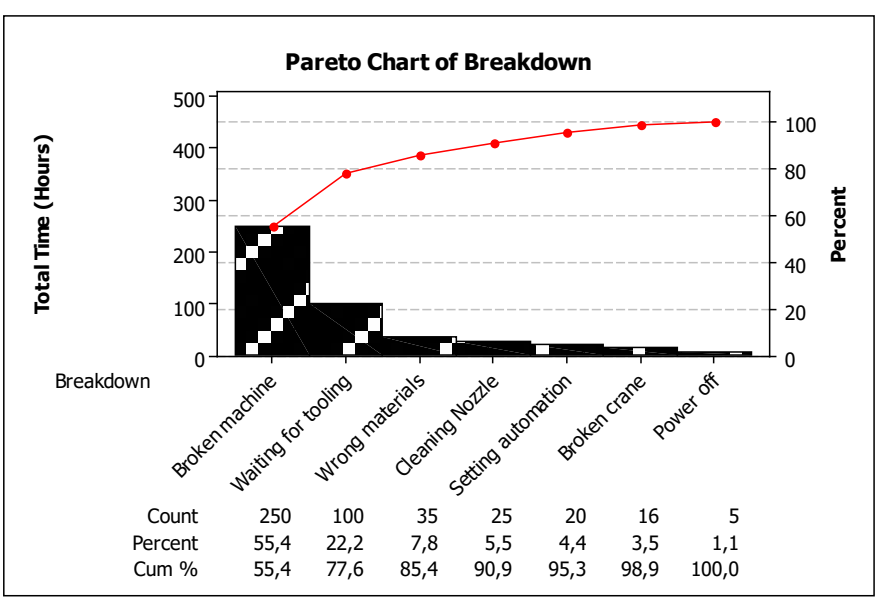

Figure 5 Pareto Chart of the Breakdown

Based on Figure 5, the broken machine and waiting for tooling are the most dominant factors for a breakdown. These two types of breakdown contribute $77,6 \%$ of the total breakdown. Then, it is followed by wrong material with $7,8 \%$. Since the broken machine is the highest contributor for breakdown, it needs to do a deep analysis to determine the root cause.

The root cause analysis for the breakdown uses 5-Why and the fishbone diagram. The analysis shows the root causes. It is shown as Why 1 to answer question 1, Why 2 to answer question 2, and others. Table 14 describes the breakdown of the production.

Table 14 The 5-Why Analysis Data

\begin{tabular}{|c|c|c|}
\hline Factors & $\begin{array}{l}\text { 5-Why } \\
\text { Analysis }\end{array}$ & Problem Description \\
\hline \multirow[t]{5}{*}{ Machine } & Why 1 & Oil in the machine is too hot \\
\hline & Why 2 & The heat exchanger does not work well \\
\hline & Why 3 & The heat exchanger is corroded \\
\hline & Why 4 & The heat exchanger is never clean \\
\hline & Why 5 & There is no chemical for cleaning \\
\hline \multirow[t]{5}{*}{ Method } & Why 1 & $\begin{array}{l}\text { It spends more time to improve or } \\
\text { repair the machine }\end{array}$ \\
\hline & Why 2 & It has fewer preparations \\
\hline & Why 3 & Some spare parts are not available \\
\hline & Why 4 & There is no system for the spare parts \\
\hline & Why 5 & - \\
\hline \multirow[t]{5}{*}{ Man } & Why 1 & $\begin{array}{l}\text { The employee has an uneven mechanic } \\
\text { skill }\end{array}$ \\
\hline & Why 2 & The employee has less skill \\
\hline & Why 3 & There is no knowledge transfer \\
\hline & Why 4 & $\begin{array}{l}\text { There is no system for knowledge } \\
\text { transfer }\end{array}$ \\
\hline & Why 5 & - \\
\hline \multirow[t]{5}{*}{ Material } & Why 1 & Heater band is easy to burn out \\
\hline & Why 2 & The size of the material is not standard \\
\hline & Why 3 & It has wrong preparation \\
\hline & Why 4 & - \\
\hline & Why 5 & - \\
\hline
\end{tabular}



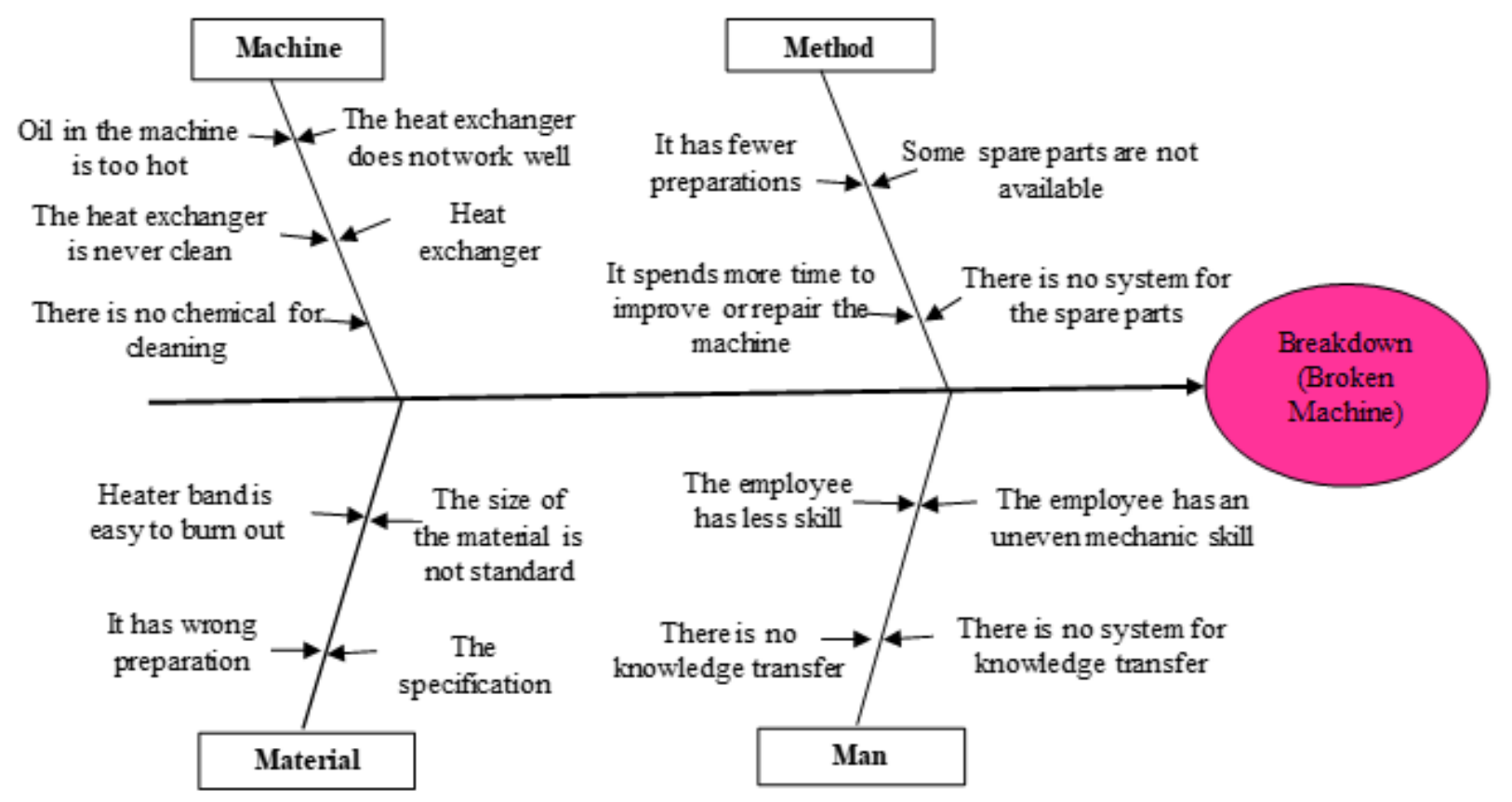

Figure 6 Fishbone Diagram for a Broken Machine

Table 15 Failure Mode and Effect Analysis (FMEA) List

\begin{tabular}{|c|c|c|c|c|c|c|c|}
\hline No & $\begin{array}{l}\text { Potential Failure } \\
\text { Mode (s) }\end{array}$ & Severity & Problem & Detection & RPN & Root Cause and Improvements & Due Date \\
\hline 1 & $\begin{array}{l}\text { The oil in the } \\
\text { machine is too hot }\end{array}$ & 8 & 9 & 8 & 576 & $\begin{array}{l}\text { Root cause: no chemical for cleaning heat } \\
\text { exchanger (machine). } \\
\text { Improvement: providing the proper } \\
\text { chemical for cleaning heat exchanger } \\
\text { (machine). }\end{array}$ & $\begin{array}{l}\text { April } \\
2020\end{array}$ \\
\hline 2 & $\begin{array}{l}\text { It spends more time } \\
\text { to improve or repair } \\
\text { machine }\end{array}$ & 7 & 8 & 7 & 392 & $\begin{array}{l}\text { Root cause: no system for spare part } \\
\text { (method). } \\
\text { Improvement: optimizing Enterprise } \\
\text { Resource Planning (ERP) to control spare } \\
\text { parts and implementing SMED for every } \\
\text { repair machine activity. }\end{array}$ & $\begin{array}{l}\text { April } \\
2020\end{array}$ \\
\hline 3 & $\begin{array}{l}\text { The employee has } \\
\text { an uneven mechanic } \\
\text { skill }\end{array}$ & 8 & 6 & 8 & 384 & $\begin{array}{l}\text { Root cause: no system for transferring } \\
\text { knowledge (man). } \\
\text { Improvement: conducting On the Job } \\
\text { Training (OJT). }\end{array}$ & $\begin{array}{l}\text { June } \\
2020\end{array}$ \\
\hline 4 & $\begin{array}{l}\text { Heater band is easy to } \\
\text { burn out }\end{array}$ & 7 & 7 & 6 & 294 & $\begin{array}{l}\text { Root cause: the wrong size of heater band } \\
\text { material due to wrong preparation. } \\
\text { Improvement: modifying the heater band } \\
\text { for high dimensions from } 15 \mathrm{~mm} \text { to } 60 \\
\mathrm{~mm} \text {. }\end{array}$ & $\begin{array}{l}\text { April } \\
2020\end{array}$ \\
\hline
\end{tabular}

In the meantime, the fishbone diagram is used to determine the root cause. The fishbone diagram can also be called the cause and effect diagram. It is from some ailments, such as machine, method, material, and man as the causes. As shown in Figure 6, the broken machine is a problem that needs to be analyzed to determine the possibility of the root cause.

After the root cause of the breakdown has been determined, it is necessary to determine the priority level for making improvements. The used method determines priority levels with FMEA. The FMEA list is shown in Table 15. Based on Table 15, the root cause is the too hot oil in the machine with an RPN value of 576. It is followed by spending more time to improve or repair the machine. After conducting improvement in a certain area, Table 16 shows the data by comparing before and after the improvement. 
Table 16 OEE Data Before and After the Improvement

\begin{tabular}{cccccc}
\hline \multicolumn{2}{c}{ Months } & A & P & Q & OEE \\
\hline \multirow{4}{*}{ Before } & Oct & 61,61 & 45,08 & 99,54 & 27,65 \\
& Nov & 60,49 & 45,92 & 98,76 & 27,43 \\
& Dec & 42,82 & 54,63 & 98,79 & 23,11 \\
& Average & 54,97 & 48,54 & 99,03 & 26,43 \\
\hline \multirow{4}{*}{ After } & Jan & 93,37 & 85,04 & 99,96 & 79,37 \\
& Feb & 85,79 & 96,40 & 99,92 & 82,64 \\
& Mar & 76,90 & 95,98 & 99,88 & 73,72 \\
& Average & 85,35 & 92,48 & 99,92 & 78,87 \\
\hline
\end{tabular}

Note: $\mathrm{A}=$ Availability, $\mathrm{P}=$ Performance, and $\mathrm{Q}=$ Quality.

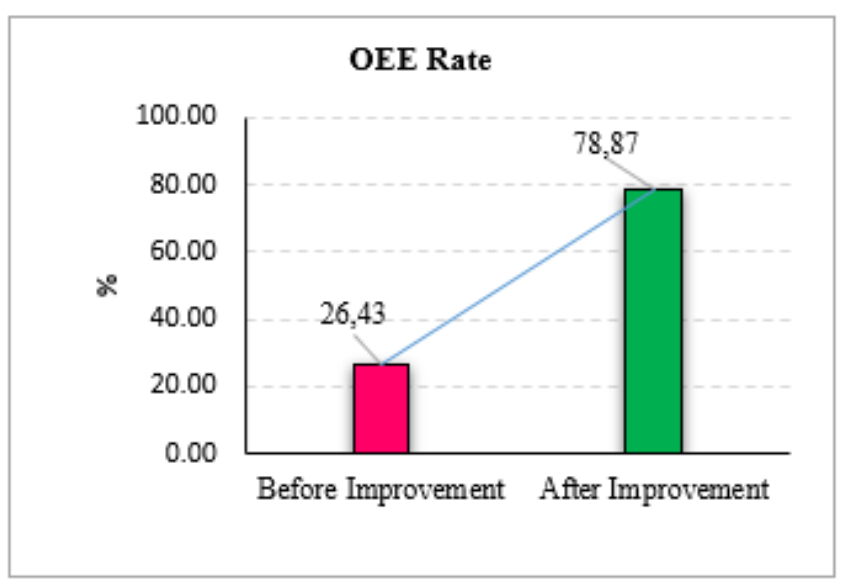

Figure 7 The OEE Rate Before and After Improvement

\section{CONCLUSIONS}

By following the whole framework of the research, it can be concluded that there are several causes of why the OEE does not meet the target. First, the machine is not well maintained because of no chemical for cleaning the heat exchanger. Thus, the oil in the machine is too hot. Second, the used method does not have an excellent system to control spare parts. It takes more time to repair a machine. Third, the company does not have a system for knowledge transfer for the man factor, so the employees' skills are not even. Fourth, for material, the heater band is too small, so it is easy to break.

All causes contribute to the breakdown losses. Hence, the improvement has been done. The manufacture prepares the chemical for cleaning the heat exchanger, implements ERP and SMED to squeeze times in repairing the machine, and creates more job training for better knowledge transfer. Moreover, the material for heater band diameter is changed from 15 to $60 \mathrm{~mm}$ to extend its lifetime. All improvements have a positive impact on the company.

The OEE rate increases from an average of $26,43 \%$ to $78,87 \%$. There is an increase of $52,44 \%$. The value of availability improves from $54,97 \%$ to $83,35 \%$. For performance rate. it increases from
$48,54 \%$ to $92,48 \%$. Then, in the quality rate, there is an increase from $99,03 \%$ to $99,92 \%$. It means the OEE rate reaches the company target of $75 \%$. However, it still has not reached the OEE target, following worldclass companies with a minimum of $85 \%$. It still has room to increase the OEE rate achievement at this company by maintaining the whole system.

There are several limitations in the research. First, the research scope is only the plastic manufacturing industry. It focuses on Toshiba injection molding machine number 42/IS 450 GSW. Second, the research is related to the downtime or stoppage by analyzing it using FMEA. It is also supported by other tools such as the Pareto chart, CED, and six big losses analyses.

Further discussion is needed to maintain what has been successfully achieved. It is highly recommended to use the FMEA by combining it with other quality improvement tools like Six Sigma. It has a detail of how to do an improvement process with Define, Measure, Analyze, Improve, and Control (DMAIC). Hence, it will be more accurate to make justifications for the improvements.

\section{REFERENCES}

Ahuja, I. P. S., \& Singh, P. (2012). Application of analytical hierarchy process for justification of TPM implementation in manufacturing organisations. International Journal of Technology, Policy and Management, 12(1), 37-47.

Badli Shah, M. Y. (2012). Total Productive Maintenance: A study of Malaysian automotive SMEs. In Proceedings of the World Congress on Engineering (pp. 1460-1464).

Benjamin, S. J., Murugaiah, U., \& Marathamuthu, M. S. (2013). The use of SMED to eliminate small stops in a manufacturing firm. Journal of Manufacturing Technology Management, 24(5), 792-807.

Biro Pusat Statistik (BPS). (2018). Laju pertumbuhan indsutri makanan dan minuman. Retrieved from https://lokadata.beritagar.id/chart/preview/ laju-pertumbuhan-indsutri-makanan-danminuman-2013-2018-1563426644\#

Ćatić, D., \& Glišović, J. (2019). Failure Mode, Effects and Criticality Analysis of mechanical systems' elements. Mobility and Vehicle Mechanics, 45(3), 25-39.

Cheah, C. K., Prakash, J., \& Ong, K. S. (2020). Overall Equipment Effectiveness: A review and development of an integrated improvement framework. International Journal of Productivity and Quality Management, 30(1), 46-71.

Chong, K. E., Ng, K. C., \& Goh, G. G. G. (2015). Improving Overall Equipment Effectiveness (OEE) through integration of Maintenance Failure Mode and Effect Analysis (Maintenance-FMEA) in a semiconductor manufacturer: A case study. In 2015 IEEE International Conference on Industrial Engineering and Engineering Management (IEEM) (pp. 14271431). IEEE. 
Chrysler LLC, Ford Motor Company, \& General Motors Corporation. (2008). Potential Failure Mode and Effect Analysis (FMEA) (4 ${ }^{\text {th }}$ ed.). AIAG

Dal, B., Tugwell, P., \& Greatbanks, R. (2000). Overall Equipment Effectiveness as a measure of operational improvement - A practical analysis. International Journal of Operations \& Production Management, 20(12), 1488-1502.

Darsin, M. (2020). Aplikasi Overall Equipment Effectiveness (OEE) dalam upaya mengatasi tingginya downtime pada stasiun ketel di PG X Jawa Timur. Multitek Indonesia, 13(2), 95-103.

Dunford, R., Su, Q., \& Tamang, E. (2014). The pareto principle. The Plymouth Student scientist, 7(1), 140148.

Gandhi, D. N., \& Deshpande, V. (2018). A review of TPM to implement OEE technique in manufacturing industry. Industrial Engineering Journal, XI(6), 3646.

Gidey, E., Beshah, B., \& Kitaw, D. (2014). Review on the evolving relationship between quality and productivity. International Journal for Quality Research, 8(1), 47-60.

Gupta, A. K., \& Garg, R. K. (2012). OEE improvement by TPM implementation: A case study. International Journal of IT, Engineering and Applied Sciences Research, 1(1), 115-124.

Lazim, H. M., Salleh, M. N., Subramaniam, C., \& Othman, S. N. (2013). Total Productive Maintenance and manufacturing performance: Does technical complexity in the production process matter. International Journal of Trade, Economics and Finance, 4(6), 380-383.

McDermott, R. E., Mikulak, R. J., \& Beauregard, M. (2009). The basic of FMEA ( $2^{\text {nd }} \mathrm{ed}$.). CRC Press

Mad Lazim, H., \& Ramayah, T. (2010). Maintenance strategy in Malaysian manufacturing companies: A Total Productive Maintenance (TPM) approach. Business Strategy Series, 11(6), 387-396.

Mardono, U., Rimawan, E., Pratondo, T., \& Saraswati, I. (2019). An analysis of the effect of elimination of six big losses on increasing profitability in steel rolling mill companies. International Journal of Mechanical and Production Engineering Research and Development, 9(2), 387-398.

Nakajima, S. (1988). Introduction to TPM: Total Productive Maintenance. Productivity Press, Inc.

Nasution, M. N. (2005). Manajemen mutu terpadu. Ghalia Indonesia.

Nallusamy, S., \& Majumdar, G. (2017). Enhancement of Overall Equipment Effectiveness using Total Productive Maintenance in a manufacturing industry. International Journal of Performability Engineering, 13(2), 173-188.

Nurprihatin, F., Angely, M., \& Tannady, H. (2019). Total Productive Maintenance policy to increase effectiveness and maintenance performance using Overall Equipment Effectiveness. Journal of Applied Research on Industrial Engineering, 6(3), 184-199.

Prabowo, H. A., Suprapto, Y. B., \& Farida, F. (2018). The evaluation of eight pillars Total Productive
Maintenance (TPM) implementation and their impact on Overall Equipment Effectiveness (OEE) and waste. Sinergi, 22(1), 13-18.

Pinjar, M. V. N., Shivakumar, S., \& Patil, G. V. (2015). Productivity improvement through Single Minute Exchange of Die (SMED) technique. International Journal of Scientific and Research Publications, $5(7), 1-9$.

Reddy, A. S. N., Rao, P. S., \& Rajyalakshmi, G. (2016). Productivity improvement using time study analysis in a small scale solar appliances industry-A case study. ARPN Journal of Engineering and Applied Sciences, 11(1), 666-674.

Ranjan, R., \& Mishra, A. (2016). Evaluation and optimization of Overall Equipment Effectiveness on a pasting machine in a battery manufacturing industry. International Journal of Performability Engineering, 12(6), 503-512.

Rusman, M., Parenreng, S. M., Setiawan, I., Asmal, S., \& Wahid, I. (2019). The Overall Equipment Effectiveness (OEE) analysis in minimizing the Six Big Losses: An effort to green manufacturing in a wood processing company. IOP Conference Series: Earth and Environmental Science, 343, 012010

Salonen, A., \& Deleryd, M. (2011). Cost of poor maintenance: A concept for maintenance performance improvement. Journal of Quality in Maintenance Engineering, 17(1), 63-73.

Samuel, A. U., Oyawale, F., \& Fayomi, O. S. I. (2019). Analysis and reduction of waste in beverage industries using Pareto principle and value stream mapping. Journal of Physics: Conference Series, 1378, 1-13.

Sangameshwran, P., \& Jagannathan, R. (2002). HLL's manufacturing renaissance. Indian Management, November, 30-35.

Shakil, S. I., \& Parvez, M. (2018). Application of lean manufacturing in a sewing line for improving Overall Equipment Effectiveness (OEE). American Journal of Industrial and Business Management, 8(9), 1951-1971.

Shirose, K. (1995). TPM team guide. Productivity Press.

Singh, R., Gohil, A. M., Shah, D. B., \& Desai, S. (2013). Total Productive Maintenance (TPM) implementation in a machine shop: A case study. Procedia Engineering, 51, 592-599.

Singh, M., \& Narwal, M. (2017). Measurement of Overall Equipment Effectiveness (OEE) of a manufacturing industry: An effective lean tool. International Journal of Recent Trends in Engineering and Research, 3(5), 268-275.

Siregar, A. R., Purba, H. H., \& Aisyah, S. (2017). Measuring Overall Equipment Effectiveness (OEE) palm oil mill in Indonesia. International Journal of Recent Trends in Engineering and Research, 3(12), 164170.

Supriyadi, S., Ramayanti, G., \& Afriansyah, R. (2017). Analisis Total Productive Maintenance dengan metode Overall Equipment Effectiveness dan Fuzzy Failure Mode and Effects Analysis. Sinergi, 21(3), 165-172. 
Susilo, C. F., \& Andika, A. (2016). Overall Equipment Effectiveness improvement with Total Productive Maintenance method. In 2016 Global Conference on Business, Management and Entrepreneurship.

Sutardi, A., \& Budiasih, E. (2011). Pengolahan data penjualan buku menggunakan metode klasifikasi ABC (Diagram Pareto) untuk mengidentifikasi kategori buku yang banyak diminati pembaca (Studi Kasus: PT. Elex Media Komputindo). Konferensi Nasional ICT-M Politeknik Telkom.

Tobe, A. Y., Widhiyanuriyawan, D., \& Yuliati, L. (2018). The integration of Overall Equipment Effectiveness (OEE) method and lean manufacturing concept to improve production performance (Case study: Fertilizer producer). Journal of Engineering and Management in Industrial System, 5(2), 102-108.

Waghmare, S. N., Raut, D. N., Mahajan, S. K., \& Bhamare, S. S. (2014). Failure Mode Effect Analysis and Total Productive Maintenance: A review. International Journal of Innovative Research in Advanced Engineering, 1(6), 183-203.
Wahyudin, B. I. S., \& Hasibuan, S. (2019). Analysis for enhancing quality and productivity using Overall Equipment Effectiveness and statistical process control in manufacturing industry case study: Manufacturing industry sport shoes in Tangerang region. International Journal of Innovative Science and Research Technology, 4(12), 108-114.

Xu, Z., \& Dang, Y. (2020). Automated digital cause-andeffect diagrams to assist causal analysis in problemsolving: A data-driven approach. International Journal of Production Research, 58(17), 5359-5379.

Yusuf, B., Rahman, A., \& Himawan, R. (2015). Analisa Overall Equipment Effectiveness untuk memperbaiki sistem perawatan mesin DOP berbasis Total Productive Maintenance (Studi kasus: PT XYZMalang). Jurnal Rekayasa dan Manajemen Sistem Industri, 3(1), 99-109.

Zammori, F., Braglia, M., \& Frosolini, M. (2011). Stochastic Overall Equipment Effectiveness. International Journal of Production Research, 49(21), 6469-6490. 